\title{
Validity, Rule of Recognition and Stability: Revisiting Analytical Concepts from the Law-Morals Connection
}

\section{MIGUEL ÁLVAREZ ORTEGA}

In 1987, R.N. Moles claimed that Hart had developed "an account of law which is extremely superficial," "retrograde" and "misconceived" (Moles $1987,8,114)$. Radical as it may appear, the quotation is to some extent representative of a critical approach that started in the late eighties and consolidated in the nineties, mainly due to the prevalence of much more sophisticated models for the study of Law such as those put forward by Dworkin and Alexy.

However, Hartian categories have somehow retained their vigour within Legal Theory, and significant attempts to explore their potential have been made in the last twenty years. In this paper, I shall try to show the conditions under which these categories may still have some utility, with reference to the work of the Argentine philosopher Ernesto Garzón Valdés. Primarily known for his normative ethics studies and socio-political research relating to Latin-American issues, Garzón also investigates Legal Theory problems with a distinctive analytical methodology. The impact of Herbert Hart on the orientation and resolution of this sort of analytical legal questions is remarkable. In fact, one of the earliest studies in Spanish on Hart's work was a paper by Garzón Valdés on "Legal validity, efficacy and existence in H.L.A. Hart" (Garzón Valdés 1967). Garzón had had the chance to study Hart's The Concept of Law and to discuss it with his friend and colleague Eugenio Bulygin, an internationally recognised scholar specialising in normative logics and legal systems.

However, Garzón's primary influence was not Hartian, but rather Kelsenian. His PhD dissertation was a powerful and extensi ve critique of the Natur der Sache ("The Nature of Things") revival that took place in 
post-war Germany mainly due to Gustav Radbruch's abandonment of pure legal positivism (Radbruch 1960). Kelsen's formalism and radical separation of Law and Morals appeared to Garzón as the proper way to fight a corpus doctrinarum that could not avoid the naturalistic fallacy. However, a later attempt to clarify the notion of legal validity (Garzón Valdés 1977) made him aware of the failures and problems of the Reine Rechstlehre in providing a comprehensive and coherent vision of Law. From that point on, the Hartian influence is such that it may be said that the rest of Garzón's works on legal theory make continuous reference to Hart, although his opinion on its value is not at all constant. An examination of the evolution of Garzón's position on Hartian concepts may provide some clues for a better understanding of the conditions under which these concepts retain their explanatory potential. The following discussion attempts to explain this evolution, in three stages: (1) moderate critique: the problem of legal validity; (2) reassessment of the rule of recognition: the concept of stability; (3) the relation between Law and Morality: towards a conceptual link.

\section{Moderate Critique: The Problem of Legal Validity}

The way Garzón Valdés chooses to approach the conceptualization of legal validity is a suggestive one, based upon the comparison of several models corresponding to different philosophical traditions. As the standard reference in the field, the Kelsenian model is taken as the starting point for comparison. Its description goes as follows:

1. Taking into account that rules belong to the Sollen (ought-to-be), their validity cannot be derived from or based on a bare fact.

2. "The validity of a rule is its specific way of existence." Hence, existence $=$ validity.

3. Should a rule be valid, there exists a duty of obedience and a sanction in case of infringement.

4. "A rule is valid when it has been enacted by the competent organ and according to the proper procedure" (Garzón Valdés 1993a, 74-7; Kelsen 1934, 62ff.).

This approach is criticized by Garzón, in the first place, because it leads to unavoidable recursion. If, as Kelsen suggests, the validity of a norm depends on some other norm's validity, and validity cannot be applied to the ultimate rule (the Grundnorm, according to which "one should behave as the Constitution prescribes"), then the rest of the rules are not valid either (Garzón Valdés 1993a, 93-4). As for postulate 3, Kelsen seems to be yielding to the naturalistic fallacy, since the problem of the duty of obedience is a moral one that cannot be solved by means of sheer formal 
legality. Postulates 1 and 4 seem to present fewer problems. Only radical legal realism or radical versions of the Natur der Sache doctrine would attempt to defend a factual concept of validity. Postulate 4 may in some way be regarded as the core definition of validity. Unless there was a minimum consensus about it, we could hardly be referring to the same issue when discussing validity. (Garzón Valdés 1993a, 93; Nino 1985, 175ff.)

Having rejected Kelsen's approach, Garzón explores the Hartian alternative, that may be described as follows:

1. Postulate 1 is somehow explicitly accepted, since Hart makes reference to "this form of fallacy of arguing from what is to what should be" (Hart 1963, 28).

2. Postulate 2 is discarded: we cannot talk about validity or invalidity regarding the ultimate rule of the system, the rule of recognition. Its existence is a factual question (Hart 1994, 110).

3. Postulate 3 is rejected: It does not make any sense to talk about a duty of obedience regarding secondary rules, that is, those conferring legal authority to both public and private actors. Conflicts between legal and moral rules are openly admitted (Hart 1994, chaps. 5 and 9; Bayles 1992, 44).

4. Postulate 4 is reformulated as follows: Validity is an internal statement about the exigencies of the "rule of recognition" (Hart 1994, 103).

Regarding the first polemical postulate, i.e., postulate 2, Garzón shows that there are two different concepts of existence, depending on the type of rule to be discussed. The first concept refers to primary and secondary rules, meaning they are valid according to the criteria of the system. The second concept applies to the rule of recognition: existence here is an external statement, a matter of fact (Hart 1994, 110). This last idea seems problematic for Garzón, because according to Hart:

[We] have to remember that the last rule of recognition can be considered from two points of view: One is expressed in the factual external statement that the rule exists in the real practice of the system; the other one is expressed in the internal validity statements formulated by those who use it to identify the law. (Hart 1994, 111).

But [Garzón claims] it would seem that internal statements cannot be formulated for the rule of recognition, because it then would be valid, a statement that Hart would not accept. (Garzón Valdés 1993a, 92)

Postulate 3 (validity = duty of obedience) is rejected for two reasons: (i) there is a certain type of rule that does not contain a mandate or command, but rather confers legal authority (secondary rules), and (ii) conflicts between moral and legal prescriptions are admitted. Regarding 
the first idea, Ramos Pascua argues that, in Hart, "the legal validity statements are always legal compulsory statements," explicitly confronting Garzón's position. A duty of obedience may be derived from secondary rules, albeit in an indirect manner (Ramos Pascua 1989, 147). I think that this disagreement about interpretation is a superficial one, originating from terminological confusion. While Ramos Pascua refers to prescription as an inner legal quality, Garzón is referring to the secondary rules as an intellectual progress predating Austin's conception of rules as commands. In this respect, it may be useful to distinguish between a broad notion of duty of obedience and a narrow one, referring to the special structure of some kind of rules, called "primary" by Hart, that are meant to require or prohibit particular behaviour on the part of the addressees (Hacker 1977, 1-26).

The quotation from Ramos Pascua relates to the second reason mentioned above. Here, the question of whether Hart considers that every valid rule bears a duty of obedience is much more complicated. In spite of Hart's insistence in keeping a sharp conceptual separation between Law and Morality, the contact points between these two spheres are varied and problematic within Hart's works (especially when discussing the rule of recognition). It may be sufficient, for the purpose of this essay, to argue that the well-known formula "[t]his is law; but too iniquitous to be applied or obeyed"(Hart 1994, 208), clearly rules out an alignment of this author with the two major positions defending the law-duty of obedience identification, i.e., Kelsenian formalism and ontological Natural Law doctrines.

Regarding postulate 4, Hart's definition of validity as an internal statement of compliance with the exigencies of the rule of recognition is regarded by Garzón as highly problematic. According to Garzón, Hart's definition may easily lead to a theory of recognition similar to the "autonomy of law" defended by Rudolf Laun, since, eventually, validity would seem to depend on the public and private actors' compliance with the rule of recognition (Garzón Valdés 1993b, 107-17). Garzón defends:

I do not think that this conclusion could satisfy Hart, but I think that the limit between these two theories is extremely dim if the internal point of view and the internal statements of validity are linked to the fact of "acceptance" of the rule and that only the ones accepting it "have an obligation" [...] [W]e may ask ourselves to which extent [...] [Hart's model] is consequent with its denial of postulate 3 precisely regarding those who adopt the internal point of view, i.e., those who make the statements of validity. (Garzón Valdés 1993a, 93).

Garzon's general conclusion is that the Hartian approach to the concept of validity is less problematic than that of Kelsen, but it is not free of criticism either. Its main utility lies in the placing of the problem within the boundaries of existing legal systems (Garzón Valdés 1993a, 102). In this 
regard, Hart indicates that the formulation of a validity statement presupposes a general acceptance of the system as efficacious (Hart 1994, 104), that is to say, the verification of a general compliance of valid rules and an acceptance of the rules of recognition by public officials:

There are therefore two minimum conditions necessary and sufficient for the existence of a legal system. On the one hand, those rules of behaviour which are valid according to the system's ultimate criteria of validity must be generally obeyed, and on the other hand, its rules of recognition specifying the criteria of legal validity and its rules of change and adjudication must be effectively accepted as common public standards of official behaviour by its officials. (Hart 1994, 116).

Yet the adduced logical problems lead Garzón to take elements from the works of Von Wright to complete the Hartian approach. The membership of the last rule of the system (the sovereign rule, in Von Wright's terminology) is sustained as a definitional property, instead of a factual one. This last rule is neither valid nor invalid (Von Wright 1963, 199; Garzón Valdés 1993a, 90-1, 99).

Garzon's early reading of Hart may generally be considered a misleading one. The attempt to make the internal point of view appear as some sort of theory of recognition is based on a misinterpretation. The aim of Hart's formulation is not to make validity or duty of obedience dependent upon individual conscience. Nor do these conclusions seem to be indirectly derivable from his thoughts. According to Hart, a rule is valid if it eventually complies with the exigencies of the rule of recognition. Those making statements of validity usually take an internal point of view regarding the acceptance of that rule, yet this acceptance does not make the rule of recognition a valid one. As the rule of recognition is a legal standard that is shown in the practice of actors, its acceptance is a prerequisite of the statements of validity. This does not mean that each actor may freely determine the existence of the rule or its concrete legal derivations. As for the duty of obedience, it should be remembered that the distinction between "to have an obligation" and "to be obligated" is based on the verification of the existence of a rule in the first expression, a question that does not depend upon individual conscience or will (Bayles 1992, 48, 53).

\section{Reassessment of the Rule of Recognition: The Concept of Stability}

At a later stage, Garzón Valdés makes use of the Hartian rule of recognition in order to elucidate the concept of the stability of political systems. First, he attempts to describe stability as a dispositional property related to other essential and contingent properties of the system, and then makes the attempt to develop an appropriate concept of stability. I will try to show 
the problems that the use of the rule of recognition in the context of political systems presents and the value that Garzón's construction upon a Hartian notion may have in its original field: the legal system.

\subsection{Properties of the System}

It is usually accepted that the central problem when discussing stability is the configuration of the unity of the system, showing the model to be used to understand its identity. It is with such an end that the rule of recognition is used, since it provides the membership and validity criteria that in turn enable the identification of a determinate system. It has to be said that this rule not only refers to constitutions, but also to principles, maximae and implementation guidelines that are not relevant in positive law. Hence the difficulty found in the identification of a rule, especially if we take into account that it is not unusual (especially in the Latin American context) to notice a wide divergence between the declared internal point of view and the one effectively adopted (Garzón Valdés 1987, 16, 61).

Should the notion of stability be related to the identity and unity of a system, the question of the existence of such a system has to be addressed first of all. According to Garzón, a political system has the following necessary and sufficient features:

i. the internal point of view reflecting the acceptance of the rule of recognition by the dominant sector in society, whose size varies along with the particular political regime, and

ii. those who adopt the internal point of view having the power to impose that rule (ibid., 17, 21).

The idea of acceptance is used here in a strong sense, meaning "legitimation," i.e., a description of the belief in the correctness of the system (not mere compliance due to apathy or prudential reasons). As a descriptive concept, its normative equivalent is "legitimacy" (ibid., 7).

The contingent features of a system are those that may or may not be a part of a particular political system. Among them are:

i. Legitimacy: ethical correctness based upon the ideas of autonomy and equal access to the goods needed to develop any personal life plan (ibid., 45). The UN Universal Declaration of Human Rights may be an adequate reference. Considering the number of countries that do not respect the Declaration, it is not hard to defend the feature as contingent.

ii. Stability: In a general and almost intuitive way, it could be said that a system is stable if it shows a tendency to react, under certain circumstances and within a determinate period of time, in such a way 
that would enable it to maintain its identity. Stability is considered a dispositional property, and in the sense established by Carnap and Ryle, it is understood to refer to a "certain capacity, tendency or propensity" (ibid., 11-2).

The stated separation does not mean that there are no possible relations between legitimacy, legitimation and stability. The legitimacy found in solid democracies upholding the rule of law may explain the necessary support to determine their existence (legitimation) and provide good stability grounds. And democratic legitimation may provide good reasons to defend legitimacy, but a democracy is not per se a guarantee of the respect for human rights (ibid., 8-9). The idea is that a necessary connection has to be rejected, since political systems may be: legitimate and stable, legitimate and unstable, illegitimate and stable, and illegitimate and unstable. The second part of Garzon's book is dedicated to analyzing Latin American examples of these four categories.

\subsection{The Definition of Stability}

An accurate definition of stability requires an in-depth approach to the notion of identity, and to the changes that are compatible with its preservation. Context and time boundaries also need to be determined.

In addressing this task, Garzón rejects a merely formal approach as a consequence of the above-mentioned description of the rule of recognition. A change that is implemented following the provisions laid down in the Constitution does not necessarily respect its identity, unless some mechanisms are adopted for this purpose. The prohibition of some valid constitutional reforms may be a good example. The existence of such reforms is not a guarantee of stability, since revolution is always a possibility, the outcome of which depends upon the power of conflicting factions (Garzón Valdés 1987, 27-8).

Hence, Garzon's proposal is a material one:

If the change is made following the "rule of recognition" we have an identity reaction. That is why the validity of the rules of change and the validity changes made following their provision cannot be determined taking into account just their constitutional legality. The complex criteria included within the rule of recognition in order to identify valid rules of the system have also to be considered (ibid., 30).

Here, Garzón makes use of the expressions "mutation" and "explanation" regarding the changes, meaning that when some alteration mutates the rule of recognition, the identity of the system collapses, while if the change may be considered as an explanation of the aforementioned rule, we have an identity reaction (ibid., 31). 
The instances allowing these reactions may be classified as borderline cases, referring to the internal point of view and/or the capacity of imposing the internal point of view. These cases are mainly the following: a) detection of internal contradictions in the rule of recognition, b) inability to offer a sound response to problems taking place within the system and leading to frustration, and c) problems and conflicts resolvable through an explanation of the rule of recognition. This last case cannot be regarded as an ordinary implementation of the rules of the system, because it gives rise to the need to find an urgent and complex explanatory solution to avoid being forced to opt for mutation. However, the existence of these sorts of cases is not sufficient to question stability. We also need to verify that: i. the only way to give a proper response to a borderline case implies the mutation of the rule of recognition, and ii. that the rule of recognition does not have sufficient support to prevail (ibid., 33, 38-40).

As for the relevant timeframe, it is necessary to recognize the need for contextualization. Any assessment of stability depends on historical and geographical factors that determine the admissible frequency of changes within a given timeframe (ibid., 43).

Considering the elements analysed, the final proposal states:

A determinate political system is stable if and only if, in cases related to institutionalised exercise of power-may these be "normal" or "borderline," it has the tendency to react in such a way that changes are an efficacious explanation of the "rule of recognition" and this tendency remains for a significant lapse of time according to its historical and regional context. (Ibid., 44)

\subsection{Political System vs. Legal System}

From a technical point of view, the term "political system" may be considered one of the multiple applications that systems theory has had in the domain of social science. The sociologist Talcott Parsons, father of structural functionalism, is a key actor in this theoretical movement (see Parsons 1952; 1968). In political science, different scholars have developed their own particular systematic approach to the political field. Let us consider systemic-functionalists such as Almond and Powell (1966) or Easton (1953), according to whom the defining feature that distinguishes a political system before other social interactions is its authoritative value assignment function. Easton holds that a political system consists of: political community, regime and authority norms and structures. The key factor for the survival of the system is its ability to offer a response to perturbations, so that it can adapt to circumstances (Easton 1953; 1957). The term has also been used by organization theorists (Cyert and March 1963), institutionalists (Huntington 1968), and rational-choice theorists (Downs 1973; Elster 2000). 
Following Alcántara Sáez, a broad definition containing the main contributions so far stated may be put forward. A political system may be said to contain the following subsystems: institutional elements or regime; institutional actors that act as citizens' agents dealing with government; historical, cultural and political values; the international sphere in which it is located (Alcántara Sáez 1994). As a result, it may be said that regardless of the nuances and variations in each theoretical construct, the notion of system is here just a technical-sociological attempt to offer a comprehensive understanding of the multiple elements, actors and factors in the public arena through a particular vision of their reciprocal interaction.

As for the notion of "legal system," this notion is used here in quite a peculiar way, thus explaining the continental preference for the term legal "order," especially since Santi Romano published his L'ordinamento giuridico in 1917. Here, the legal order (ordinamento giuridico) may be defined as a set of rules characterized by unity, coherence and completeness, according to classical Dogmatics. Following Bobbio (1960, 25ff., 69ff., $125 \mathrm{ff}$.), we can say that unity (unità) refers to the problem of having a connection with a common or fundamental rule (Kelsen) or with legal hierarchy; coherence (coerenza) implies the need to resolve antinomies; completeness (completezza) requires mechanisms to fill legal gaps. As Mario Losano (2002) has pointed out, Romano's institutional theory is an application of the notion of system to legal analysis, an academic task that has continued since German Pandectistic to present times. However, most western languages prefer the expression "legal order" to legal system (English is the most significant exception), mainly because of the difficulties found in a full implementation of the formal-logical concept of system to Law. In Logic, a system is said to be composed of a set of axioms and a set of theorems. Coherence means that axioms are compatible with each other, so a contradiction will destroy the system. Completeness requires every theorem to be governed by axioms. In addition, axioms are considered necessary and independent from each other (Losano 2002, 195ff.). As a result if we consider that legal coherence requires the solution of the contradiction, and not the collapse of the system, it seems evident that the notion of system used in Logic does not fully apply to Law (Bobbio 1960, 80). This also explains why it is not uncommon to reconsider the classical characteristics and take them as an ideal model or methodological device that should guide both legislatures and judges, assuming that they are properties that Law is likely to have, or just redefine their meaning. In any event, it seems clear that the idea of "system" as outlined above cannot be identified as equivalent to that found in political science.

Turning back to the "rule of recognition," it is worth recalling that it was conceived by Hart as an attempt to explain the complex institutional practice that identifies rules as valid and pertaining to the legal system, hence showing itself as the last legal standard. It is in this sense that 
Garzón (1987, 16, 61) makes use of the rule as a key element in his research. But one may wonder whether the change of scenario to the wider and vaguer background of political systems is a legitimate theoretical implementation. The second part of Garzón's book provides an interesting set of examples from Latin America. According to Atienza and Ruiz Manero (1986), the inclusion of a "benefactor-State capitalism" in the case of Costa Rica is an example of a misuse of the rule of recognition. However, Garzón argues that the expression only refers to the idea of a Welfare State, a common element in many Constitutions and therefore both a political guide and a legal validity standard (Atienza and Ruiz Manero 1986, 418). It is important to note that the questioned element is a constitutional provision that allows the rule of recognition to perform the functions assigned by Hart. But we have to take into account that Garzón relates varied elements such as support for mining companies, the fight against Anglo-Saxon Protestantism, or judicial corruption (Garzón Valdés 1987, 47, 51, 61, 67). It is difficult to argue that purely sociological or economical elements (many of which also have some circumstantial character) determine legal membership and are characterized by such a high level constitutional relevance that their modification would imply a mutation of the rule of recognition. This does not mean that those elements have no influence in the political arena and may not be considered as valuable tools to comprehend the factors influencing social life. It does not mean that Garzón's proposal lacks importance either. If the use of the rule of recognition gives rise to a risk of distorting its functions when applied to political systems, the perspective must be changed.

Coming back to Legal Theory, Garzón's research is of great value in order to defend an axiological and political view of the legal system. Let us consider the problem of unity, identity and stability referred this time to legal systems. It is known that legal systems contain rules relating to change, the constitutional reform clauses being the most important of them. Change is therefore a normal adaptation function, but its validity is no guarantee that the system will maintain its identity. According to Vilajosana, one should choose a material criterion to establish the existence of an alteration of identity: the "relevance" of the change with regard to the political regime. He intends his proposal to be superior to Garzon's, that he calls a "materialized" version of the rule of recognition. According to Vilajosana, the main problem with Garzón's theory is that any alteration taking place in the rule of recognition would signify a modification of the system's identity (Vilajosana 1996, 60ff.; Finnis 1973, 69ff.).

The material criterion defended in this approach may be regarded as a useful one, yet the criticism of Garzón is excessive. It is true that some passages may suggest the possibility of considering a change in the rule of recognition as an unavoidable alteration of identity, but Garzón also 
concedes the possibility of a valid constitutional reform that respects the identity of the system, should there be a clause protecting an axiological institutional core. We could therefore argue that the "relevance criterion" supported by Vilajosana is somehow implicit in Garzón's work, meaning that not every change in the rule of recognition necessarily leads to a change of identity.

These last arguments enable us to conclude that the rule of recognition provides membership and validity criteria referring to a core of values and principles. These seem to be the elements that Hacker refers to when he writes: "the principle of unity does not lie in a single norm but in aspects of a number of norms" (Hacker 1977, 24). As a result, should this core be preserved, the system holds its particular identity. We could then say that a legal system is stable if it is capable of providing adequate explanations of its nucleus, i.e., if it is not forced to mutate due to a lack of public support or to the inability to offer a sound response to both "borderline" (contradictions, frustrated claims, new conflicts) and ordinary cases that arise in its implementation. This new perspective of the problem at stake can be considered as a step forward with respect to Hart's thesis, leading to an open defense of a Law-Morals conceptual link, as I will try to show below.

\section{The Relation between Law and Morality: Towards a Conceptual Link}

We have already seen how Garzón states that "legitimation"—-considered as an acceptance of the rule or recognition-has to be distinguished from sheer routine acquiescence or compliance due to prudential reasons. It is problematic to explain the existence of a legal system, i.e., to describe the complex attitude of those supporting the system.

Yet, according to Rolf Sartorius, a Hartian positivist, one only needs to verify that officials enforce valid rules and that the majority of citizens comply with them in order to defend the existence of a legal system: an inquiry about their motivations appears to be unnecessary (Sartorius 1987; Skubik 1990, 113). Considering this position, Garzón describes an imaginary State in which "all officials had a wrong idea of the reasons motivating the behaviour of their colleagues, and where all of them, in their hearts, rejected the system" (that would be a land of error or Irrland) or a State in which there is no belief regarding the basic rules of the system, that is, where compliance is explained due to sheer habit (Apathiland) (Garzón Valdés 1999, 25-43). Garzón claims not only that these examples would be hard to find empirically or that they would present a high degree of structural instability, but that they are scarcely compatible with the thoughtful critical attitude that Hart $(1994,57)$ describes as the general mind-set of those taking the internal point of view. As a result he goes a step forward to defend the thesis that 
there is a conceptual link between law and morality, such that a legal system cannot even exist without the claim that its rule of recognition is morally right. (Garzón Valdés 1999, 31)

He also addresses the issue of the intentio dogmatica of legal actors-the judge being the paradigmatic example-according to which legal propositions present a claim to moral correctness that cannot neglect the idea of justice inherent to the system, that is, the one sustained by officials taking the internal point of view (Garzón Valdés 1993c, 308). It is not the aim of Garzón to ignore the fact that some members of the public services may act due to prudential or peremptory reasons, thus producing "detached statements" (Hart 1982), but to point out that this attitude cannot be a general one. It is not his intention to deny the legal character of unjust regimes, but rather to verify the need for a claim to legitimacy in order to assess the existence of a system. Overall, Garzón's arguments lead to the conclusion that a sound and coherent description of legal systems requires an open acceptance of their link with morals. Similar conclusions were drawn taking a different path by Robert Alexy. If lawmakers and judges need a claim to correctness to avoid defective and self-contradictory legal propositions, then a descriptive conceptual connection between legal systems and positive morality has to be allowed. Furthermore, assuming the link between correctness, justification and generalizability within discursive ethics, logically implies an ideal conceptual connection between legal systems and a universal morality (Alexy 1989). The appeal of this sort of approaches is such that even a declared positivist as Raz makes use of what he calls "the claim to authority" as a necessary element to describe a legal system (Raz 1979). The extent to which this type of device is compatible with legal positivism is a matter that has given rise to a debate between Alexy and Raz and that falls outside of the scope of this paper (Alexy 2007; Raz 2009; Gardner 2008).

What matters here is that Hart's reluctance to admit such a Law-Morality nexus is considered to be the origin of a good deal of the criticism put forward by different scholars, who also sustain the need to assume the linking thesis in order to provide a sounder reading of his works (MacCormick 1978, 240-1; Fuller 1967; Raz 1981, 455; Skubik 1990, 114; De Páramo 1984,103, 250-252; Ramos Pascua 1989, 192, 195; Pérez Luño 1991, 390).

The empirical nature of the rule of recognition is not enough in itself to explain the legal character of a system (according to the well-known problems encountered when trying to move from facts to norms) (Alexy 2010). Following Scarpelli and Catania, one can argue that a foundation of values is needed (Scarpelli 1965, 81ff.; Catania 1971, 266-7). Hence Garzón's statements: 
authorities and officials would contradict themselves if they claimed that ethics did not play any role in the concept of the validity of the norms which they regard from the internal point of view. (Garzón Valdés 1999, 36)

those who adopt the internal point of view can, ultimately, only explain the validity of the norms of the system by bringing forward moral arguments. (Garzón Valdés $1999,34)$

We may consider these arguments to complete the initial position on legal validity. Garzón seems in the end to share Alfred's Verdross insight into the Kelsenean Grundnorm:

Its head rises towards the world of values, from where its normative validity can only be derived; its feet are stuck in the firm sociological field of real human behaviour. (Verdross 1931, 354-5)

\section{Conclusions}

Much has been written about the now classic work The Concept of Law. The vagueness and ambiguity of the terms employed have led some to suggest that Hart's work can be considered as providing a powerful set of concepts that need further elaboration, rather than a conclusive study (Hacker 1977, 1). This has led a number of scholars to respond either with shallow critical remarks or just unthinking disdain (Moles 1987, 81, 114). Yet one may wonder whether Legal Theory may still benefit from Hart's formulations and adopt a more constructive perspective. In a recent essay, La Torre tries to explore the capabilities of the Hartian thesis to address the legal character of international "Law." Though he explicitly opposes Hart's position-that is, he denies the legal character based on the lack of secondary rules in the international sphere-he chooses to interpret the rule of recognition from a post-Dworkinean perspective. Thus, a richer vision emerges, according to which the entrance of (moral) principles in the rule of recognition makes it possible to identify a legal character in International Law (La Torre 2007).

In this essay I have tried to proceed likewise. I have attempted to show how the attitude towards Hart's legal theory has prompted Garzon's philosophical evolution from an unfounded rejection to an awareness of the potential lying in his notions, and a need to overcome his positivist separation thesis in order to provide a sound account of legal phenomena. The rule of recognition, the key concept in the exposition, may not lack problems or perplexities, as many scholars argue, yet it does not present the risks primarily suggested by Garzón. It seems to be quite a useful tool for elucidating a concept of stability of legal systems (rather than political ones, as Garzón tried to achieve), provided we do not neglect the need to consider the internal point of view as a moral one. Two main conclusions may therefore be drawn. First, the notions created by Hart still have 
considerable potential to address controversial issues. Second, in order to fulfil this potential, a closer relation between Law and Morality has to be accepted, as the latest tendencies in Legal Theory (both positivist and naturalistic) seem to indicate.

\author{
Facultad de Derecho \\ Universidad de Sevilla \\ C/ Enramadilla 18-20, \\ 41018, Sevilla, Spain \\ E-mail:mao@us.es
}

\title{
References
}

Alcántara Sáez, Manuel. 1994. Gobernabilidad, crisis y cambio. Madrid: CEC.

Alexy, Robert. 1989. On Necessary Relations between Law and Morality. Ratio Juris 2(2): 167-83.

Alexy, Robert. 2007. An Answer to Joseph Raz. In Law, Rights and Discourse. Ed. George Pavlakos, 37-55. Oxford: Hart.

Alexy, Robert. 2010. The Argument from Injustice: A Reply to Legal Positivism, (translated by Bonnie Litschewski Paulson and Stanley L. Paulson). Oxford: Oxford University Press.

Almond, Gabriel A., and Powell, G. Bingham. 1966. Comparative Politics: A Developmental Approach. Boston: Little Brown \& Co.

Atienza, Manuel and Ruiz Manero, Juan. 1986. Entrevista con Ernesto Garzón Valdés. Doxa 4: 413-26.

Bayles, Michael D. 1992. Hart's Legal Philosophy. An Examination. Dordrecht: Kluwer.

Bobbio, Norberto. 1960. Teoria dell'ordinamento giuridico. Turin: Giappichelli.

Catania, Alfonso. 1971. L'accettazione nel pensiero di Herbert, L. A. Hart. RIFD 48: 261-79.

Cyert, Richard M., and James G. March. 1963. A Behavioural Theory of the Firm. New York: Prentice Hall.

De Páramo, Juan R. 1984. H. L. A. Hart y la teoría analítica del derecho. Madrid: CEC.

Downs, Anthony. 1973. Teoría económica de la democracia. Madrid: Aguilar.

Easton, David. 1953. The Political System: An Inquiry into the State of Political Science. New York: Alfred A. Knopf.

Easton, David. 1957. An Approach to the Analysis of Political Systems. World Politics 11: 393-400.

Elster, Jon. 2000. Rational Choice History: A Case of Excessive Ambition. American Political Science Review 94: 685-95.

Finnis, John. 1973. Revolutions and Continuity of Law. In Oxford Essays in Jurisprudence: Second Series. Ed. A.W.B. Simpson. Oxford: Oxford University Press.

Fuller, Lon. 1967. La moral del derecho. Mexico City: Trillas.

Gardner, John. 2008. How Law Claims, What Law Claims. Oxford Legal Studies Research Paper 44.

Garzón Valdés, Ernesto. 1967. Acerca de las nociones de validez, eficacia y existencia en H. L. A. Hart. Notas de Filosofía del Derecho 4: 23-30.

Garzón Valdés, Ernesto. 1977. Algunos modelos de validez normativa. Revista Latinoamericana de Filosofía 3: 41-68.

Garzón Valdés, Ernesto. 1987. El concepto de estabilidad de los sistemas políticos. Madrid: CEC. 
Garzón Valdés, Ernesto. 1993a. Algunos modelos de validez normativa. In Ernesto Garzón Valdés, Derecho, Etica, Política, 73-106. Madrid: CEC. (1st ed. 1977.)

Garzón Valdés, Ernesto. 1993b. Validez, eficacia y existencia en H.L.A. Hart. In Ernesto Garzón Valdés, Derecho, Ética, Politica, 107-17. Madrid: CEC.

Garzón Valdés, Ernesto. 1993c. Seguridad jurídica y equidad. In Ernesto Garzón Valdés, Derecho, Ética, Política, 301-17. Madrid: CEC. (1st ed. 1992).

Garzón Valdés, Ernesto. 1999. The Relation between Law and Morality. Associations 3: 25-43. (1st ed. in Spanish 1990.)

Hacker, Peter M.S. 1977. Hart's Philosophy of Law. In Law, Morality and Society. Essays in Honour of H.L.A. Hart. Eds. P.M.S. Hacker and Joseph Raz. Oxford: Clarendon.

Hart, H.L.A. 1963. Law, Liberty and Morality. Oxford: Oxford University Press.

Hart, H.L.A. 1982. Essays on Bentham: Studies in Jurisprudence and Political Theory. Oxford: Clarendon.

Hart, H.L.A. 1994. The Concept of Law. 2nd ed. Oxford: Clarendon.

Huntington, Samuel P. 1968. Political Order in Changing Societies. New Haven, CT: Yale University Press.

Kelsen, Hans. 1934. Reine Rechtslehre: Einleitung in die Rechtswissenschaftliche Problematik. Wien: Franz Deuticke.

La Torre, Massimo. 2007. The Hierarchical Model and H.L.A. Hart's Concept of Law. ARSP 93: 92-100.

Losano, Mario. 2002. Sistema e struttura nel diritto. Milan: Giuffrè.

MacCormick, Neil. 1978. Legal Reasoning and Legal Theory. Oxford: Clarendon.

Moles, Robert N. 1987. Definition and Rule in Legal Theory. A Reassessment of H.L.A. Hart and the Positivist Tradition. Oxford: Basil Blackwell.

Nino, Carlos Santiago. 1985. La validez del derecho. Buenos Aires: Astrea.

Parsons, Talcott. 1952. The Social System. London: Tavistock.

Parsons, Talcott. 1968. La estructura de la acción social: estudio de teoría social con referencia a un grupo de recientes escritores europeos. Madrid: Guadarrama.

Pérez Luño, Antonio E. 1991. ¿Qué deber? Consideraciones sobre el deber de obediencia al derecho con especial referencia a la teoría de H.L.A. Hart. In Obligatoriedad y derecho: XII Jornadas de Filosofía Jurídica y Social. Oviedo: Universidad de Oviedo.

Radbruch, Gustav. 1960. Die Natur der Sache als Juristische Denkform. Darmstadt: Wissenschaftliche Buchgesellschaft. (1st ed. 1948.)

Ramos Pascua, J. A. 1989. La regla de reconocimiento en la teoría jurídica de H.L.A. Hart. Madrid: Tecnos.

Raz, Joseph. 1979. The Authority of Law. Essays on Law and Morality. Oxford: Clarendon.

Raz, Joseph. 1981. The Purity of the Pure Theory. Revue internationale de philosophie 138: 441-59.

Raz, Joseph. 2009. Appendix II. The Argument from Justice. In Joseph Raz, The Authority of Law. Essays on Law and Morality. 2nd ed. Oxford: Oxford University Press.

Romano, Santi. 1917. L'ordinamento giuridico. Pisa: Mariotti.

Sartorius, Rolf. 1987. Positivism and Foundations of Legal Authority. In Issues in Contemporary Legal Philosophy. The Influence of H.L.A. Hart. Ed. Ruth Gavison. Oxford: Clarendon.

Scarpelli, Uberto. 1965. Cos'è il positivismo giuridico. Milan: Comunità.

Skubik, Daniel W. 1990. At the Intersection of Legality and Morality. Hartian Law as Natural Law. New York: Peter Lang. 
Verdross, Alfred. 1931. Die allgemeinen Rechtsgrundsätze als Völkrrechtsquelle. In Alfred Verdross, Gesellschaft, Staat und Recht: Untersuchungen zur Reine Rechtslehre. Vienna: Julius Sprenger.

Vilajosana, J. María. 1996. Towards a Material Criterion of Identity of a Legal Order. Rechstheorie 27: 46-64.

von Wright, Georg Henrik. 1963. Norm and Action. A Logical Enquiry. London: Routledge \& Kegan Paul. 